\title{
Humoral immune responses of antibacterial hemocyanin (Ab-Hcy) in mud crab, Scylla serrata
}

\author{
Meiyalagan Velayutham *,1, Arumugam Munusamy \\ Department of Zoology, University of Madras, Guindy Campus, Chennai 600 025, Tamil Nadu, India
}

\section{A R T I C L E I N F O}

\section{Article history:}

Received 5 April 2016

Received in revised form 18 July 2016

Accepted 19 July 2016

Available online 20 July 2016

\section{Keywords:}

Scylla serrata

Hemocyanin

Antibacterial

Humoral functions

\begin{abstract}
A B S T R A C T
Hemocyanins are large extracellular respiratory proteins distributed within the hemolymph of arthropods, molluscs and larval stages of certain insects. In the present study, we characterized the humoral immune functions of cation specific antibacterial hemocyanin (Ab-Hcy) from mud crab, S. serrata. The bacteriolytic activity of Ab-Hcy was against pathogenic and non-pathogenic to crustaceans which includes, Bacillus sp. N1, B. flexus N3, E. coli, P. aeruginosa, $V$. harveyi, $V$. parahaemolyticus and $V$. vulnificus and also expressed bacteriostatic activity against $E$. coli, B. flexus N3 and V. harveyi. The agglutination activity of Ab-Hcy ranged from 4-16 against B. flexus N3, E. coli, V. harveyi and V. vulnificus and Ab-Hcy also agglutinated with rat and human $\mathrm{O}$ erythrocytes (HA titer: 2). The Ab-Hcy lysed the panel of mammalian erythrocytes and strong hemolytic activity of 1.40, 1.28 and 1.22 units $\cdot \min ^{-1} \cdot \mathrm{mg}$ protein ${ }^{-1}$ against human $\mathrm{A}, \mathrm{B}$ and $\mathrm{O}$ erythrocytes respectively. It was also found that the $\mathrm{Ab}-\mathrm{Hcy}$ possess phenoloxidase (PO) activity by oxidizing L-DOPA. These results suggest that Ab-Hcy from the serum of mud crab, S. serrata, is capable of performing multiple humoral immune functions in addition to oxygen transportation.

Statement of relevance: This manuscript deals with the humoral immune functions, particularly antibacterial property of hemocyanin in crustacean. In this paper we report the different type of antibacterial activity and other humoral immune functions of a hemocyanin isolated from the serum of mud crab, Scylla serrata. This work will help to understand the role of respiratory molecule in immune system, also will be helpful improve disease free crustacean aquaculture industry.

And we also state this research work is relevant and suitable to publish in the Journal "Aquaculture".
\end{abstract}

(c) 2016 Elsevier B.V. All rights reserved.

\section{Introduction}

Crustaceans are the second largest group, next to insects, in the phylum Arthropoda, approximately > 30,000 known species (Bachère et al., 2004). Crustacean production is a worldwide economic activity with prime importance in intertropical developing countries. It is important to note the intensification of crustacean aquaculture farming over the last few decades has been accompanied by the development of infectious diseases from viral, bacterial, and in some cases, fungal origin (Destoumieux-Garzón et al., 2001). In recent years, many investigations focused on crustacean immunity to overcome the above mentioned diseases and better productivity. Crustacean immunity has two distinct immune system i.e., humoral and cellular defense mechanism. Hemocytes play a central role in cellular immune system by phagocytosis, encapsulation and nodule formation, whilst humoral factors are agglutinins, killing factors, lysins, precipitins, cytokine-like molecules and clotting

\footnotetext{
* Corresponding author.

E-mail address: meiyazhagan1982@live.com (M. Velayutham).

1 Present address: Department of Diagnosis and Surgery, School of Dentistry at Araraquara, Sao Paulo State University, Rua Humaita, 1680, 14801-903 Araraquara, Sao Paulo, Brazil.
}

agents (Hauton, 2012; Smith and Chisholm, 1992; Söderhäll and Cerenius, 1992). Crustaceans lack of defined immunoglobulins and are incapable of adaptive immunity, but are known to contain repertoire humoral molecules that mediate various types of immune responses against non-self materials. These defense mechanisms depend completely on the innate immune system that is activated when pathogen-associated patterns recognize molecules, such as lectins, antimicrobial, clotting, and pattern recognition proteins, which turn and activate cellular or humoral immune mechanisms to destroy invading pathogens (Vazquez et al., 2009).

In crustaceans, the major protein components of hemolymph are copper containing hemocyanins. They typically represent up to 95\% of the total amount of protein in the crustacean hemolymph (Horn and Kerr, 1969; Jayasree, 2001). Hemocyanins are extracellular giant copper containing protein found in the hemolymph of both molluscs and arthropods, performing multiple physiological functions, such as oxygen transport, osmoregulation, protein storage or enzyme activities (Decker et al., 2007; Markl, 2013; Paul and Pirow, 1997) and also contributing to development, homeostasis and immune defenses within marine invertebrates (Coates and Nairn, 2014).

The previous studies have reported several humoral immune functions of hemocyanin apart from the oxygen transportation. The clotting 
enzyme of the horseshoe crab, Tachypleus tridentatus, functionally converts hemocyanin to phenoloxidase (Nagai and Kawabata, 2000). Tachyplesin a major antimicrobial peptide from T. tridentatus, converted the hemocyanin to phenoloxidase (Nagai et al., 2001). Cold-adapted hemocyanin-derived phenoloxidase activity is important to the survival of crab Erimacrus isenbeckii (Kim et al., 2011). It is also notable that the hemocyanins of kuruma prawn Penaeus japonicus and crayfish Gastrolith functions as phenoloxidases in the presence of sodium dodecyl sulfate (SDS) (Adachi et al., 2008; Glazer et al., 2013).

Earlier studies also reported the crustacean hemocyanin appear to possess antimicrobial property in two distinguished forms: (i) antimicrobial proteins act as activators of hemocyanin and (ii) hemocyanin itself is the source of antimicrobial proteins (Decker and Jaenicke, 2004; Kawabata et al., 1995; Lee et al., 2003). Recently we have reported, the cation metals specific hemocyanin ( $305 \mathrm{kDa}$ ) with three or four possible subunits (70 to $98 \mathrm{kDa}$ ) from serum of mud crab, Scylla serrata, possesses a significant antibacterial activity against host/resident specific bacterial species including Gram-positive B. flexus N3 and Gram-negative E. coli, V. harveyi and V. vulnificus (Meiyalagan and Arumugam, 2015; Meiyalagan et al., 2016). The antibacterial activity caused by this hemocyanin is not clear, so it is necessary to know whether the activity is due to bacterial agglutination, bacteriolytic, bactericidal or bacteriostatic activity. Thus, in this study we attempted to investigate the specific type of antibacterial activity in addition to other possible humoral immune functions of the antibacterial hemocyanin from the mud crab, Scylla serrata.

\section{Material and methods}

\subsection{Isolation of $A b-H c y$}

Ab-Hcy was isolated by anion exchange chromatography. Briefly, serum (25 mg total protein) was passes through pre-equilibrated diethylaminoethyl cellulose (DEAE cellulose) matrix with PBS (10 mM; pH 7.0). The bound materials were eluted with gradient increase of $0.0-0.5 \mathrm{M} \mathrm{NaCl}$ and then protein content of every fractions $(1 \mathrm{ml})$ were monitored at $280 \mathrm{~nm}$. The antibacterial activity was tested and the fractions which invariably showed antibacterial activity were pooled together and used for further characterization (Meiyalagan et al., 2016).

\subsection{Bacteriolytic activity}

The bacteriolytic activity was assayed following Shugar (1952). $15 \mu \mathrm{g} / \mathrm{ml}$ of the isolated antibacterial hemocyanin (Ab-Hcy) was and mixed with bacterial suspension (0.5 O.D. at $570 \mathrm{~nm}$ ), incubated for $90 \mathrm{~min}$ at $23^{\circ} \mathrm{C}$ and centrifuged ( $3500 \mathrm{rpm}$ for $10 \mathrm{~min}$ ). The optical density of supernatant was read at $450 \mathrm{~nm}$ and the bacteriolytic activity was expressed as units $\cdot \mathrm{min}^{-1} \cdot \mathrm{mg}_{\text {protein }}{ }^{-1}$.

\subsection{Bacteriostatic activity}

The bacteriostatic activity was determined with modifications in method of Forrest (1972). Ab-Hcy $(15 \mu \mathrm{g} / \mathrm{ml})$ was mixed with bacterial suspension and this mixture was incubated at $37^{\circ} \mathrm{C}$ for $10 \mathrm{~h}$ with frequent shaking. At $1 \mathrm{~h}$ intervals, to $0.1 \mathrm{ml}$ of this mixture, $10 \mu \mathrm{l}$ of MTT [3-(4,5-dimethylthiazol-2-yl)-2,5-diphenyltetrazolium bromide] $\left(5 \mathrm{mg} / \mathrm{ml}\right.$ ) was added and re-incubated for $30 \mathrm{~min}$ at $30{ }^{\circ} \mathrm{C}$. The formazan development was read at $570 \mathrm{~nm}$ using ELISA plate reader (Power wave XS biotek).

\subsection{Bacterial agglutination activity}

The bacterial agglutinating activity was determined in U-bottom microtiter plate (Griener, Nürtingen, Germany) by serial two-fold dilution (Ueda et al., 1991). Briefly, $50 \mu \mathrm{l}$ of Ab-Hcy $(15 \mu \mathrm{g} / \mathrm{ml}$ ) was mixed with an equal volume of TBS (50 mM tris- $\mathrm{HCl} ; 115 \mathrm{mM} \mathrm{NaCl} ; 10 \mathrm{mM}$ $\mathrm{CaCl}$; $\mathrm{pH} 7.5$ ). After dilution, $50 \mu \mathrm{l}$ of bacterial suspension (0.5 O.D. at $570 \mathrm{~nm}$ ) were added to each well, incubated for $1 \mathrm{~h}$ at room temperature and kept overnight at $10{ }^{\circ} \mathrm{C}$, then the bacterial agglutinating activities observed under microscope.

\subsection{Hemagglutination activity}

The hemagglutination assays were performed in V-bottom microtiter plates (Greiner, Nürtingen, Germany) by serial two-fold dilution of $25 \mu \mathrm{l}$ of Ab-Hcy $(15 \mu \mathrm{g} / \mathrm{ml})$ with an equal volume of TBS. After dilution, $25 \mu \mathrm{l}$ of RBC (1.5\%) suspension we added to each well and incubated for $45 \mathrm{~min}$ at $26^{\circ} \mathrm{C}$.

The agglutination titers were recorded as the reciprocal of the highest dilution of the sample causing complete agglutination of bacteria/erythrocytes (Garvey et al., 1979). Controls for all assays consisted of substitution of the sample with TBS.

\subsection{Hemolytic activity}

Hemolytic activity was determined as previously described by Nagatomo (1995). Briefly, Ab-Hcy (15 $\mu \mathrm{g} / \mathrm{ml})$ mixed with $0.5 \%(\mathrm{v} / \mathrm{v})$ erythrocyte suspension and incubated for $1 \mathrm{~h}$ at $37^{\circ} \mathrm{C}$. The unbroken cells and cell debris were removed by centrifugation at $3500 \mathrm{rpm}$ for $10 \mathrm{~min}$. The optical density of the supernatant was read at $540 \mathrm{~nm}$ against suitable blank. The $0.5 \%(\mathrm{v} / \mathrm{v})$ erythrocyte suspension was treated with double distilled water and PBS (10 mM, pH 6.0) as $100 \%$ and $0 \%$ hemolysis control, respectively.

\subsection{Phenoloxidase (PO) activity}

The phenoloxidase activity were assayed by mixing $200 \mu$ of Ab-Hcy $(15 \mu \mathrm{g} / \mathrm{ml})$ with $200 \mu \mathrm{l}$ of $5 \mathrm{mM} \mathrm{L}$-DOPA prepared in tris- $\mathrm{HCl}$ buffer ( $50 \mathrm{mM}, \mathrm{pH} 7.5$ ) and incubated for $20 \mathrm{~min}$ at $25^{\circ} \mathrm{C}$. The dopachrome formed was measured in Shimadzu (UV-160A) spectrophotometer against suitable reagent blank at 490 nm (Smith and Söderhäll, 1991).

\subsection{Effect of PO inhibitors on the oxidation of L-DOPA}

In this assay, Ab-Hcy with equal volume of $3 \mathrm{mM}$ PTU (phenylthiourea) or $16 \mathrm{mM}$ tropolone containing $16 \mathrm{mM} \mathrm{H}_{2} \mathrm{O}_{2}$ were incubated for 15 min at $25{ }^{\circ} \mathrm{C}$. In controls, these chemicals were substituted with tris- $\mathrm{HCl}$ buffer ( $50 \mathrm{mM}, \mathrm{pH} 7.5$ ). The reaction mixtures were then incubated with $5 \mathrm{mM} \mathrm{L-DOPA}$ for $20 \mathrm{~min}$ at $25^{\circ} \mathrm{C}$. The optical density of both control and experiments were measured spectrophotometrically at $490 \mathrm{~nm}$ and the results were expressed as $\Delta_{\mathrm{A}} 490 \mathrm{~min}^{-1} \cdot \mathrm{mg}_{\text {protein }}{ }^{-1}$.

\subsection{Statistical analysis}

The difference between control and experimental values were analysed for statistical significance using paired sample Student's ttest (Bailey, 1995).

\section{Results}

\subsection{Bacteriolytic activity}

The antibacterial hemocyanin (Ab-Hcy) from the mud crab, S. serrata showed distinct bacteriolytic activity against all the bacterial species tested viz., Bacillus sp. N1, B. flexus N3, E. coli, P. aeruginosa, V. harveyi, $V$. parahaemolyticus, and $V$. vulnificus. The highest level of bacteriolytic activity were observed against $V$. harveyi and $E$. coli with corresponding values of 0.248 and 0.202 units $\cdot \mathrm{min}^{-1} \cdot \mathrm{mg}$ protein (Fig. 1). 


\subsection{Bacteriostatic activity}

Incubation of Ab-Hcy with bacterial species isolated from the injured/wounded cuticle of the crab up to $10 \mathrm{~h}$, suppressed the growth of B. flexes after $4 \mathrm{~h}$ (Fig. 2A) and almost completely suppressed the growth of $E$. coli throughout period of incubation (Fig. 2B). Similarly Ab-Hcy significantly inhibited the growth of crustacean pathogenic bacteria. This bacteriostatic effect was found to be more pronounced against $V$. harveyi when compared to $V$. vulnificus (Fig. 2C \& D).

\subsection{Bacterial agglutination activity}

Ab-Hcy agglutinated with all the four bacterial species viz., B. flexus N3, E. coli, V. harveyi and V. vulnificus with titers of $8,16,4$ and 16 respectively (Table. 1 ). The results clearly show that the agglutination activities were recorded with E. coli and V. vulnificus (titer: 16).

\subsection{Hemagglutination activity}

This isolated antibacterial hemocyanin (Ab-Hcy) of S. serrata, agglutinated only with two types of erythrocytes (rat and human erythrocytes) and this agglutination was found to be weak (titer : 2) while Ab-Hcy completely failed to agglutinate with other mammalian erythrocytes mentioned in Table 2.

\subsection{Hemolytic activity}

The hemolytic activity (expressed as units $\cdot \mathrm{min}^{-1} \cdot \mathrm{mg}_{\text {protein }}{ }^{-1}$ ) of Ab-Hcy was observed to be effective against all the six erythrocyte types tested such as human A, B, O, buffalo, ox and sheep, ranging from 0.19 to 1.4 units $\cdot \min ^{-1} \cdot \mathrm{mg}$ protein ${ }^{-1}$. Ab-Hcy very effectively lyses all the human erythrocytes tested including human A $(1.4 \pm$ 0.002 units $\cdot \mathrm{min}^{-1} \cdot \mathrm{mg}$ protein $\left.{ }^{-1}\right)$, human B $(1.278 \pm$ 0.005 units $\cdot \mathrm{min}^{-1} \cdot \mathrm{mg}$ protein $\left.{ }^{-1}\right)$ and human $\mathrm{O}(1.22 \pm$ 0.003 units $\cdot \min ^{-1} \cdot \mathrm{mg}$ protein ${ }^{-1}$ ) when compared with other mammalian erythrocytes including buffalo, ox and sheep RBCs (Table. 3 ).

\subsection{Phenoloxidase activity}

The oxidation rate of the Ab-Hcy phenolic substrate (L-DOPA) was be $0.0198 \pm 0.004$ units $\cdot \mathrm{min}^{-1} \cdot \mathrm{mg}$ protein ${ }^{-1}$ and the oxidation of L-
DOPA by Ab-Hcy was significantly $(p<0.005)$ inhibited by PTU a known phenoloxidase inhibitor. On the other hand, Ab-Hcy treated with tropolone did not significantly affect the oxidation of L-DOPA $\left(0.0125 \pm 0.003 \Delta_{490} \mathrm{~min}^{-1} \cdot \mathrm{mg}\right.$ protein $\left.{ }^{-1}\right)$ when compared to buffer treated control (Table 4).

\section{Discussion}

Hemocyanins the large extracellular negatively charged proteins (Jaenicke and Decker, 2003) and distributed within the hemolymph of arthropods, molluscs and larval stages of certain insects (Decker and Jaenicke, 2004; Pick et al., 2008, 2009). Previously, many investigators have demonstrated multiple humoral defense functions of hemocyanin decapod crustaceans including agglutination (=lectin like), phenoloxidase activity and hemolytic activity (Decker et al., 2001; García-Carreño et al., 2008; Lee et al., 2004; Yan et al., 2011a, 2011b; Zhang et al., 2009). Recently, antibacterial protein isolated from the serum of mud crab, S. serrata was demonstrated for its antibacterial activity against B. flexus N3, E. coli, V. harveyi and V. vulnificus. This antibacterial protein was characterized as a native hemocyanin with native molecular weight of $305 \mathrm{kDa}$, appeared to possess at least three to four subunits, capable of binding to various other metals including $\mathrm{Ca}^{2+}, \mathrm{Zn}^{2+}$ and $\mathrm{Fe}^{2+}$ (Meiyalagan et al., 2016).

The bacteriolytic activity which is, one of the attributes of antibacterial activity, in crustaceans have been reported by many investigators, however, most of these studies in decapod crustaceans have been restricted to the ability of isolated antibacterial factors as it cause lysis of Gram-positive bacteria particularly against Micrococcus luteus (de-la-Re-Vega et al., 2006; Destoumieux et al., 1997; Fenouil and Roch, 1991; Hikima et al., 2003; Tyagi et al., 2007). In the present study, analysis of bacteriolytic activity of Ab-Hcy against both Grampositive and Gram-negative bacteria revealed Ab-Hcy from $S$. serrata had significant bacteriolytic activity against both resident specific, crustacean pathogenic or non-pathogenic bacteria including Bacillus sp. N1, B. flexus N3, E. coli, P. aeruginosa, V. harveyi, V. parahaemolyticus and $V$. vulnificus (Fig. 1).

The measurement of the growth of the bacterial species viz., B. flexus $\mathrm{N} 3$, E. coli $V$. harveyi and $V$. vulnificus up to $10 \mathrm{~h}$ simultaneously incubated with Ab-Hcy presented highest bacteriostatic activity against E. coli, $B$. flexus $\mathrm{N} 3$ and $V$. harveyi (Fig. 2). These findings also derives support from the earlier works in the shrimp Penaeus monodon (Destoumieux

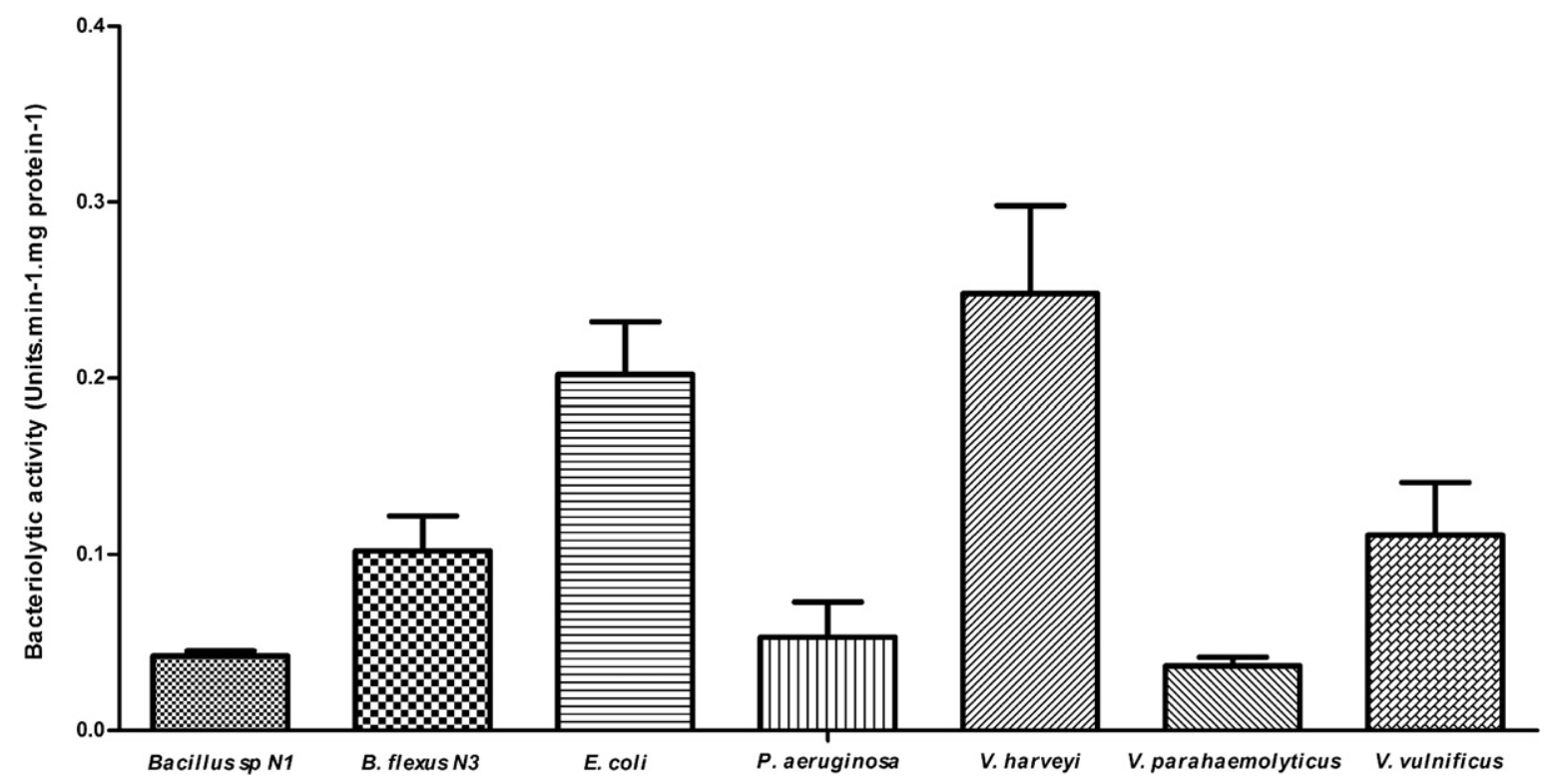

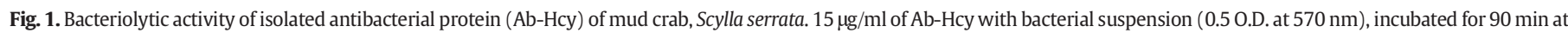
$23^{\circ} \mathrm{C}$ and O.D. was measured at $450 \mathrm{~nm}$. The bacteriolytic activity was expressed as units $\cdot \mathrm{min}^{-1} \cdot \mathrm{mg}$ protein ${ }^{-1}$. Each bar represents the mean $\pm \mathrm{SD}$ from three determinations. 
A

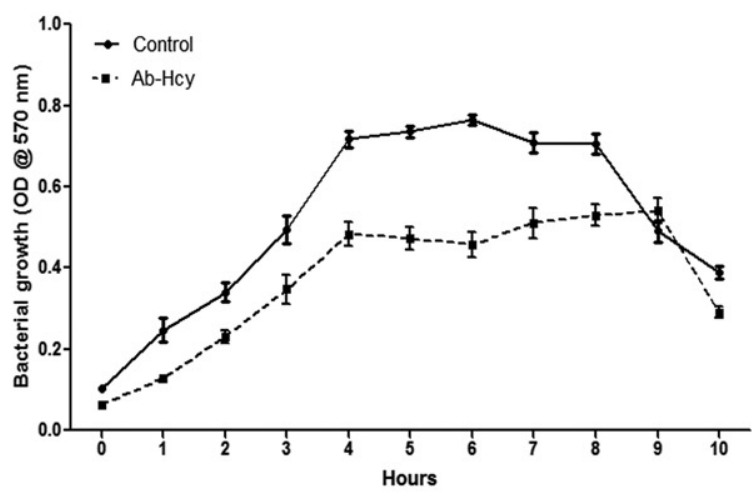

C

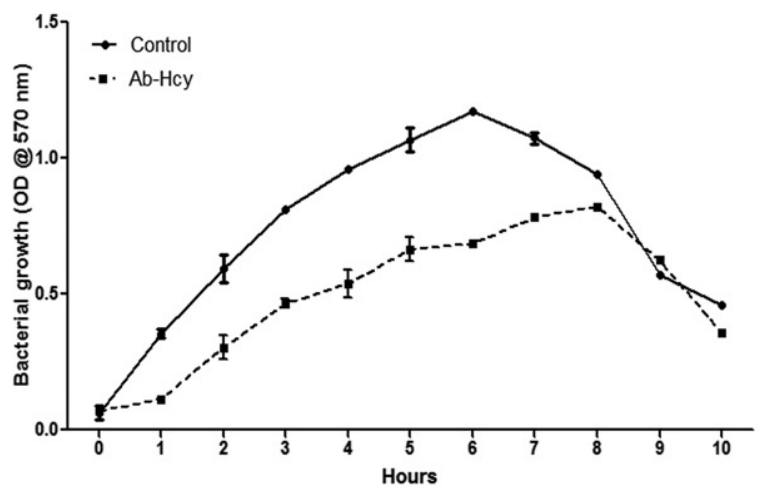

B

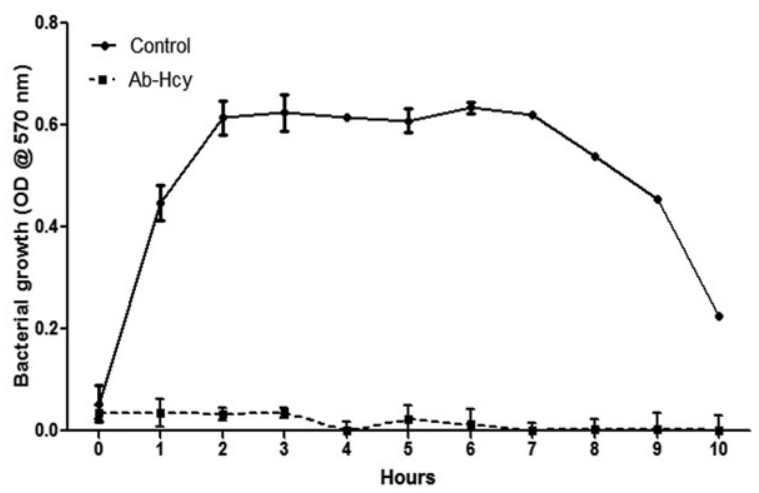

D

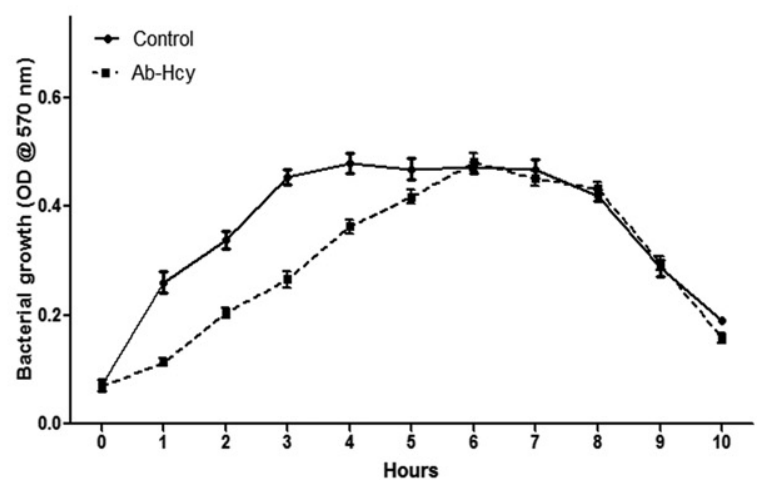

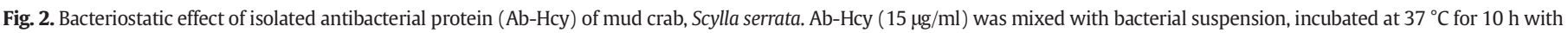

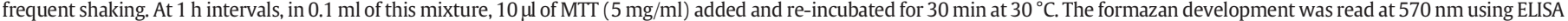
plate reader (Power wave XS biotek). Each point represents mean $\pm \mathrm{SD}$ from three determinations. A. B. flexus N3; B. E. coli; C. V. harveyi; D. V. vulnificus.

et al., 1997), where these authors have shown that an antibacterial peptide isolated from the shrimp did not kill bacteria (M. luteus) but rather inhibited its growth by bacteriostatic effect. Similarly, a synthetic tiger shrimp penaeidin-like antimicrobial peptide showed both bacteriostatic/bactericidal activity against both Gram-positive and Gram-negative bacteria (Chiou et al., 2005).

The observations from the previous studies and results from the present investigation revealed the bacteriostatic effect of the isolated antibacterial protein (Ab-Hcy) considerably differed either compared to bacteriolytic activity or bactericidal activity. This also indicating that $\mathrm{Ab}-\mathrm{Hcy}$ showed all the three types of activities viz., bactericidal, bacteriolytic and bacteriostatic activity. However, the type of antibacterial activity appeared to depend on the type of bacterial species and assay method used.

The literature pertaining to the bacterial agglutination, the hemolymph agglutinins from the shrimp Penaeus indicus ( $181 \mathrm{kDa})$, banana shrimp Fenneropenaeus merguiensis (316 kDa) showed strong agglutination activity against various Vibrio species, two Pseudomonas species and mammalian erythrocytes including human A, B, O, rat, rabbit and buffalo (Jayasree, 2001; Jayasree et al., 2000; Rittidach et al., 2007), where the bacterial agglutination activities reported were restricted with Gram-negative bacteria.

Table 1

Bacterial agglutinating activity of Ab-Hcy from mud crab, Scylla serrata.

\begin{tabular}{ll}
\hline Bacterial species tested $^{\mathrm{a}}$ & Bacterial agglutinating activity $^{\mathrm{b}, \mathrm{c}}$ \\
\hline Bacillus flexus N3 & 8 \\
Escherichia coli & 16 \\
Vibrio harveyi & 4 \\
Vibrio vulnificus & 16 \\
\hline a Optical density of each bacterial suspension was adjusted to 0.5 O.D. at $600 \mathrm{~nm}$. \\
b Data represent median values from five determination of each bacterial species. \\
c Controls for all assays consisted of substitution of the sample with TBS.
\end{tabular}

In the present study, Ab-Hcy ( $305 \mathrm{kDa}$ ) caused agglutination with both Gram-positive (B. flexus N3) and Gram-negative bacteria (viz., $E$. coli, V. harveyi and V. vulnificus) and weak agglutination with rat and human $\mathrm{O}$ erythrocytes (HA titer: 2 ). Notably, bacterial agglutination activity found in serum against $P$. aeruginosa, $V$. parahaemolyticus and $V$. anguillarum could not be detected in Ab-Hcy. On the other hand, AbHcy showed highest bacterial agglutination activity against $V$. vulnificus (titer: 16) while, serum did not agglutinated with this species of bacteria. The serum of $S$. serrata agglutinated various RBC types tested and the agglutination titers observed were ranging from 2 to 64, with highest titer of 64 for rat, mouse and buffalo, and did not agglutinate with goat erythrocytes (data not shown).

Our attempt to analyse the hemolytic activity, an attribute to the serum antibacterial protein in decapod crustaceans, the isolated AbHcy exhibited the hemolytic activity against the panel of mammalian erythrocytes (viz., buffalo, ox, sheep, human A, B and O), of which, strong hemolytic activity was observed against human $A, B$ and $O$

Table 2

Hemagglutinating activity of Ab-Hcy from mud crab, Scylla serrata.

\begin{tabular}{ll}
\hline RBC types tested & Hemagglutinating activity ${ }^{\mathrm{a}, \mathrm{b}}$ \\
\hline Rat & 2 \\
Mouse & 0 \\
Rabbit & 0 \\
Buffalo & 0 \\
Sheep & 0 \\
Ox & 0 \\
Goat & 0 \\
Human A & 0 \\
Human B & 0 \\
Human O & 2 \\
\hline a Data represent median values from five determination of each RBC type \\
tested. \\
b Controls for all assays consisted of substitution of the sample with TBS.
\end{tabular}


Table 3

Hemolytic activity of Ab-Hcy from the mud crab, Scylla serrata.

\begin{tabular}{ll}
\hline RBC types & Hemolytic activity (units $\cdot \mathrm{min}^{-1} \mathrm{mg}$ protein \\
\hline Buffalo & $0.19 \pm 0.003$ \\
Ox & $0.272 \pm 0.008$ \\
Sheep & $0.33 \pm 0.005$ \\
Human A & $1.4 \pm 0.002$ \\
Human B & $1.278 \pm 0.005$ \\
Human O & $1.22 \pm 0.003$ \\
\hline
\end{tabular}

${ }^{a}$ Results represent consistent performance from four determinations using samples from different preparations against each RBC type tested.

erythrocytes. Previously, extracts of hemolymph fractions or other tissues such as eggs, muscles and exoskeleton of various crustaceans including Pandalus borealis, Pagurus bernhardus, Hyas araneus and Paralithodes camtschatica, are known to cause lysis of human erythrocytes (Haug et al., 2002). Recently, hemocyanin from the shrimp, Litopenaeus vannamei or mud crab, $S$. serrata showed hemolytic activity against chicken erythrocytes or human A, B, AB, O, mouse, rabbit and chicken erythrocytes respectively (Yan et al., 2011b; Zhang et al., 2009).

Phenoloxidase, a copper containing enzyme, is known to play an important role in the host defense system of many invertebrates and its functions by initiating the biosynthesis of melanin for wound healing and pathogen encapsulation (Hoffmann, 1999; Söderhäll and Cerenius, 1998). Nagai and Kawabata (2000) have reported a clotting enzyme of the horseshoe crab, Tachypleus tridentatus, which functionally converted hemocyanin to phenoloxidase activity. Similarly, a chitin binding antimicrobial peptide of this horseshoe crab induced conversion of hemocyanin into an intense phenoloxidase activity (Nagai et al., 2001). Thus, these observations clearly indicate that the hemocyanin, which possesses antimicrobial activity, can show or produce phenoloxidase activity through a proteolytic cleavage by a clotting enzyme. In the present study, we have found that the antibacterial protein isolated from the serum of mud crab, S. serrata also possess phenoloxidase activity by oxidizing L-DOPA, this activation is inhibited by known PO PTU and tropolone confirming the activation of PO is one of defense mechanisms in humoral immune function.

Thus, taking together all the findings, it may be safely concluded that the antibacterial hemocyanin (Ab-Hcy) from the serum of mud crab, $S$. serrata, is capable of performing multiple antimicrobial activities including bacteriostatic, bacteriolytic, bacterial agglutinating, hemolytic as well as phenoloxidase activity, a feature often reported for either native or subunits of hemocyanin molecule(s) in the hemolymph of decapod crustaceans.

\section{Acknowledgment}

This work was carried out with funding from University Grants Commission (4-3/2006 (BSR)/5-133/2007 dated 17 Sep 2009) and Department of Biotechnology (BT/PR11998/AAQ/03/462/2009), New Delhi, India awarded to M.A. V.M. acknowledges UGC, New Delhi, India, for the award of Project Fellow.

\section{Table 4}

Effect of phenylthiourea (PTU) and tropolone on the oxidation of L-DOPA by Ab-Hcy of mud crab, Scylla serrata.

\begin{tabular}{ll}
\hline Samples tested & $\Delta_{490} \mathrm{~min}^{-1} \cdot \mathrm{mg} \mathrm{protein}^{-1 \mathrm{a}}$ \\
\hline Ab-Hcy + L-DOPA & $0.0198 \pm 0.004$ \\
Ab-Hcy + PTU + L-DOPA & $0.0021 \pm 0.003^{*}$ \\
Ab-Hcy + tropolone + L-DOPA & $0.0125 \pm 0.003$
\end{tabular}

a Oxidation of L-DOPA was determined spectrophotometrically at $490 \mathrm{~nm}$ and the values are given as mean \pm SD of three determinations using samples from different preparations.

* The difference between the oxidation of L-DOPA by Ab-Hcy with PTU are statistically significant $\left({ }^{*} p<0.005\right)$ compared to Ab-Hcy + L-DOPA.

\section{References}

Adachi, K., Hirata, T., Nagai, K., Sakaguchi, M., 2008. Hemocyanin a most likely inducer of black spots in kuruma prawn Penaeus japonicus during storage. J. Food Sci. 66 , 1130-1136. http://dx.doi.org/10.1111/j.1365-2621.2001.tb16093.x.

Bachère, E., Gueguen, Y., Gonzalez, M., de Lorgeril, J., Garnier, J., Romestand, B., 2004. Insights into the anti-microbial defense of marine invertebrates: the penaeid shrimps and the oyster Crassostrea gigas. Immunol. Rev. 198, 149-168.

Bailey, T.J.N., 1995. Statistical methods in biology. J. Mar. Biol. Assoc. United Kingdom 75, 515. http://dx.doi.org/10.1017/S0025315400018403.

Chiou, T.-T., Wu, J.-L., Chen, T.T., Lu, J.-K., 2005. Molecular cloning and characterization of cDNA of penaeidin-like antimicrobial peptide from tiger shrimp (Penaeus monodon). Mar. Biotechnol. (NY) 7, 119-127. http://dx.doi.org/10.1007/s10126-004-3164-4.

Coates, C.J., Nairn, J., 2014. Diverse immune functions of hemocyanins. Dev. Comp. Immunol. 45, 43-55. http://dx.doi.org/10.1016/j.dci.2014.01.021.

Decker, H., Jaenicke, E., 2004. Recent findings on phenoloxidase activity and antimicrobial activity of hemocyanins. Dev. Comp. Immunol. 28, 673-687. http://dx.doi.org/10. 1016/j.dci.2003.11.007.

Decker, H., Ryan, M., Jaenicke, E., Terwilliger, N., 2001. SDS-induced phenoloxidase activity of hemocyanins from Limulus polyphemus, Eurypelma californicum, and Cancer magister. J. Biol. Chem. 276, 17796-17799. http://dx.doi.org/10.1074/jbc. M010436200.

Decker, H., Hellmann, N., Jaenicke, E., Lieb, B., Meissner, U., Markl, J., 2007. Minireview: recent progress in hemocyanin research. Integr. Comp. Biol. 47, 631-644. http://dx.doi. org/10.1093/icb/icm063.

Destoumieux, D., Bulet, P., Loew, D., Van Dorsselaer, A., Rodriguez, J., Bachère, E., 1997 Penaeidins, a new family of antimicrobial peptides isolated from the shrimp Penaeus vannamei (Decapoda). J. Biol. Chem. 272, 28398-28406. http://dx.doi.org/10.1074/ jbc.272.45.28398.

Destoumieux-Garzón, D., Saulnier, D., Garnier, J., Jouffrey, C., Bulet, P., Bachère, E., 2001 Crustacean immunity. Antifungal peptides are generated from the $\mathrm{C}$ terminus of shrimp hemocyanin in response to microbial challenge. J. Biol. Chem. 276, 47070-47077. http://dx.doi.org/10.1074/jbc.M103817200.

Fenouil, E., Roch, P., 1991. Evidence and characterization of lysozyme in six species of freshwater crayfishes from Astacidae and Cambaridae families. Comp. Biochem. Physiol. Part B Comp. Biochem. 99, 43-49. http://dx.doi.org/10.1016/03050491(91)90005-X.

Forrest, W.W., 1972. Chapter X microcalorimetry. Methods Microbiol. 6, 285-318. http:// dx.doi.org/10.1016/S0580-9517(08)70601-9.

García-Carreño, F.L., Cota, K., Del Toro, M.A.N., 2008. Phenoloxidase activity of hemocyanin in whiteleg shrimp Penaeus vannamei: conversion, characterization of catalytic properties, and role in postmortem melanosis. J. Agric. Food Chem. 56, 6454-6459. http://dx.doi.org/10.1021/jf800839x.

Garvey, J.S., Cremer, N.E., Sussdorf, D.H., 1979. Methods in Immunology. W. A. Benjamin Inc., Reading, Massachusetts.

Glazer, L., Tom, M., Weil, S., Roth, Z., Khalaila, I., Mittelman, B., Sagi, A., 2013. Hemocyanin with phenoloxidase activity in the chitin matrix of the crayfish gastrolith. J. Exp. Biol. 216, 1898-1904. http://dx.doi.org/10.1242/jeb.080945.

Haug, T., Kjuul, A.K., Stensvåg, K., Sandsdalen, E., Styrvold, O.B., 2002. Antibacterial activity in four marine crustacean decapods. Fish Shellfish Immunol. 12, 371-385. http://dx. doi.org/10.1006/fsim.2001.0378.

Hauton, C., 2012. The scope of the crustacean immune system for disease control. J. Invertebr. Pathol. 110, 251-260. http://dx.doi.org/10.1016/j.jip.2012.03.005.

Hikima, S., Hikima, J., Rojtinnakorn, J., Hirono, I., Aoki, T., 2003. Characterization and function of kuruma shrimp lysozyme possessing lytic activity against Vibrio species. Gene 316, 187-195. http://dx.doi.org/10.1016/S0378-1119(03)00761-3.

Hoffmann, J.A., 1999. Phylogenetic perspectives in innate immunity. Science 284 (80), 1313-1318. http://dx.doi.org/10.1126/science.284.5418.1313.

Horn, E.C., Kerr, M.S., 1969. The hemolymph proteins of the blue crab, Callinectes sapidus. I. Hemocyanins and certain other major protein constituents. Comp. Biochem. Physiol. 29, 493-508.

Jaenicke, E., Decker, H., 2003. Tyrosinases from crustaceans form hexamers. Biochem. J. 371, 515-523. http://dx.doi.org/10.1042/BJ20021058.

Jayasree, S., 2001. Biological properties of a natural agglutinin in the hemolymph of Indian white prawn, Penaeus indicus H. Milne Edwards. Aquaculture 194, 245-252. http:// dx.doi.org/10.1016/S0044-8486(00)00528-7.

Jayasree, S., Selvam, G.S., Thomas, S., 2000. Development of an enzyme linked immunosorbent assay (ELISA) for agglutinin, an antibacterial protein of the shrimp Fenneropenaeus indicus. J. Crustac. Biol. 20, 621-627. http://dx.doi.org/10.1651/ 0278-0372(2000)020[0621:DOAELI]2.0.CO;2.

Kawabata, T., Yasuhara, Y., Ochiai, M., Matsuura, S., Ashida, M., 1995. Molecular cloning of insect pro-phenol oxidase: a copper-containing protein homologous to arthropod hemocyanin. Proc. Natl. Acad. Sci. U. S. A. 92, 7774-7778. http://dx.doi.org/10.1073/ pnas.92.17.7774

Kim, S.G., Jung, B.W., Kim, H., 2011. Hemocyanin-derived phenoloxidase activity with broad temperature stability extending into the cold environment in hemocytes of the hair crab Erimacrus isenbeckii. Comp. Biochem. Physiol. B Biochem. Mol. Biol. 159, 103-108. http://dx.doi.org/10.1016/j.cbpb.2011.02.004.

de-la-Re-Vega, E., García-Galaz, A., Díaz-Cinco, M.E., Sotelo-Mundo, R.R., 2006. White shrimp (Litopenaeus vannamei) recombinant lysozyme has antibacterial activity against Gram negative bacteria: Vibrio alginolyticus, Vibrio parahemolyticus and Vibrio cholerae. Fish Shellfish Immunol. 20, 405-408. http://dx.doi.org/10.1016/j.fsi.2005.06. 005.

Lee, S.Y., Lee, B.L., Söderhäll, K., 2003. Processing of an antibacterial peptide from hemocyanin of the freshwater crayfish Pacifastacus leniusculus. J. Biol. Chem. 278, 7927-7933. http://dx.doi.org/10.1074/jbc.M209239200. 
Lee, S.Y., Lee, B.L., Söderhäll, K., 2004. Processing of crayfish hemocyanin subunits into phenoloxidase. Biochem. Biophys. Res. Commun. 322, 490-496. http://dx.doi.org/ 10.1016/j.bbrc.2004.07.145.

Markl, J., 2013. Evolution of molluscan hemocyanin structures. Biochim. Biophys. Acta 1834, 1840-1852. http://dx.doi.org/10.1016/j.bbapap.2013.02.020.

Meiyalagan, V., Arumugam, M., 2015. Detection and preliminary characterization of antibacterial protein(s) in the serum of mud crab, Scylla serrata. Invertebr. Surviv. J. 12 287-295.

Meiyalagan, V., Sunil Kumar, K., Karthick, S., Arumugam, M., 2016. Cation metals specific hemocyanin exhibits differential antibacterial property in mud crab, Scylla serrata. Biologia (Bratisl) 71, 176-183. http://dx.doi.org/10.1515/biolog-2016-0028.

Nagai, T., Kawabata, S.I., 2000. A link between blood coagulation and prophenol oxidase activation in arthropod host defense. J. Biol. Chem. 275, 29264-29267. http://dx.doi. org/10.1074/jbc.M002556200.

Nagai, T., Osaki, T, Kawabata, S, 2001. Functional conversion of hemocyanin to phenoloxidase by horseshoe crab antimicrobial peptides. J. Biol. Chem. 276, 27166-27170. http://dx.doi.org/10.1074/jbc.M102596200.

Nagatomo, H., 1995. Interaction of the hemolytic lectin CEL-III from the marine invertebrate Cucumaria echinata with the erythrocyte membrane. J. Biol. Chem. 270, 3560-3564. http://dx.doi.org/10.1074/jbc.270.8.3560.

Paul, R., Pirow, R., 1997. The physiological significance of respiratory proteins in invertebrates. Zool. Jena 100, 298-306.

Pick, C., Hagner-Holler, S., Burmester, T., 2008. Molecular characterization of hemocyanin and hexamerin from the firebrat Thermobia domestica (Zygentoma). Insect Biochem. Mol. Biol. 38, 977-983. http://dx.doi.org/10.1016/j.ibmb.2008.08.001.

Pick, C., Schneuer, M., Burmester, T., 2009. The occurrence of hemocyanin in Hexapoda. FEBS J. 276, 1930-1941. http://dx.doi.org/10.1111/j.1742-4658.2009.06918.x.

Rittidach, W., Paijit, N., Utarabhand, P., 2007. Purification and characterization of a lectin from the banana shrimp Fenneropenaeus merguiensis hemolymph. Biochim. Biophys. Acta 1770, 106-114. http://dx.doi.org/10.1016/j.bbagen.2006.06.016.

Shugar, D., 1952. The measurement of lysozyme activity and the ultra-violet inactivation of lysozyme. Biochim. Biophys. Acta 8, 302-309. http://dx.doi.org/10.1016/00063002(52)90045-0.
Smith, V.J., Chisholm, J.R.S., 1992. Non-cellular immunity in crustaceans. Fish Shellfish Immunol. 2, 1-31. http://dx.doi.org/10.1016/S1050-4648(06)80024-0.

Smith, V.J., Söderhäll, K., 1991. A comparison of phenoloxidase activity in the blood of marine invertebrates. Dev. Comp. Immunol. 15, 251-261. http://dx.doi.org/10.1016/ 0145-305X(91)90018-T.

Söderhäll, K., Cerenius, L., 1992. Crustacean immunity. Annu. Rev. Fish Dis. 2, 3-23. http:// dx.doi.org/10.1016/0959-8030(92)90053-Z.

Söderhäll, K Cerenius, L., 1998. Role of the prophenoloxidase-activating system in invertebrate immunity. Curr. Opin. Immunol. 10, 23-28. http://dx.doi.org/10.1016/S09527915(98)80026-5.

Tyagi, A., Khushiramani, R., Karunasagar, I., Karunasagar, I., 2007. Antivibrio activity of recombinant lysozyme expressed from black tiger shrimp, Penaeus monodon. Aquaculture 272, 246-253. http://dx.doi.org/10.1016/j.aquaculture.2007.08.055.

Ueda, R., Sugita, H., Deguchi, Y., 1991. Naturally occurring agglutinin in the hemolymph of Japanese coastal Crustacea. Nippon Suisan Gakkaishi 57, 69-78. http://dx.doi.org/10. 2331/suisan.57.69.

Vazquez, L., Alpuche, J., Maldonado, G., Agundis, C., Pereyra-Morales, A., Zenteno, E., 2009. Review: immunity mechanisms in crustaceans. Innate Immun. 15, 179-188. http:// dx.doi.org/10.1177/1753425909102876.

Yan, F., Qiao, J., Zhang, Y., Zhou, N., Liu, Y., Guo, L., Li, Y., Chen, J., 2011a. Hemolytic properties of hemocyanin from mud crab Scylla serrata. J. Shellfish Res. 30, 957-962. http://dx.doi.org/10.2983/035.030.0338.

Yan, F., Zhang, Y., Jiang, R., Zhong, M., Hu, Z., Du, H., Lun, J., Chen, J., Li, Y., 2011b. Identification and agglutination properties of hemocyanin from the mud crab (Scylla serrata). Fish Shellfish Immunol. 30, 354-360. http://dx.doi.org/10.1016/j.fsi.2010. 11.004.

Zhang, Y., Yan, F., Hu, Z., Zhao, X., Min, S., Du, Z., Zhao, S., Ye, X., Li, Y., 2009. Hemocyanin from shrimp Litopenaeus vannamei shows hemolytic activity. Fish Shellifish Immunol. 27, 330-335. http://dx.doi.org/10.1016/j.fsi.2009.05.017. 